\title{
Antinociceptive effects of the essential oil of Croton zehntneri in mice
}

\author{
A.C. O liveira ${ }^{1}$ \\ J.H. Leal-Cardoso ${ }^{1}$, \\ C.F. Santos ${ }^{1}$, S.M. Morais ${ }^{2}$ \\ and A.N. Coelho-de-Souza ${ }^{1}$
}

\author{
1Departamento de Ciências Fisiológicas, Centro de Ciências da Saúde, and \\ ${ }^{2}$ Departamento de Física e Q uímica, Centro de Ciências e Tecnologia, \\ Universidade Estadual do Ceará, Fortaleza, CE, Brasil
}

\section{Correspondence \\ A.N. Coelho de Souza \\ Centro de Ciências da Saúde, UEC \\ Av. Paranjana, 1700 \\ 60740-000 Fortaleza, CE \\ Brasil \\ E-mail: \\ andrelina_noronha@ hotmail.com \\ Research supported by $\mathrm{CNPq}$ and Colégio CHRISTUS.}

Presented at the XV Annual Meeting of the Federação de Sociedades de Biologia Experimental, Caxambu, MG, Brazil, August 23-26, 2000.

Received April 13, 2000

Accepted July 19, 2001

\section{Abstract}

Croton zehntneri is an aromatic plant native to Northeastern Brazil, where it is often used in folk medicine. In the present study the antinociceptive effects of the essential oil of Croton zehntneri (EOCz) were evaluated in mice. EOCz administered orally at doses of 100 and $300 \mathrm{mg} / \mathrm{kg}$ reduced paw licking time in the second phase of the formalin test from the control value of $41.61 \pm 8.62$ to $12.01 \pm 7.97$ and $6.57 \pm 3.42 \mathrm{~s}$, respectively. During the first phase of the formalin test only $300 \mathrm{mg} / \mathrm{kg}$ induced a significant alteration (from $58.2 \pm 7.02$, control, to $28.7 \pm 4.73 \mathrm{~s}$ ). The number of contortions in response to intraperitoneal injections of acetic acid did not differ significantly between controls $(80.6 \pm 9.01)$ and experimental $(300 \mathrm{mg} / \mathrm{kg}$ body weight) animals $(89.1 \pm 9.53 \%$ of the control numbers; $\mathrm{P} \geq 0.05$, Student $t$-test). In the hot-plate test, EOCz at doses $\geq 100 \mathrm{mg} / \mathrm{kg}$ significantly increased the latency time with respect to controls (11.2 \pm 0.80 ). At 100 and $300 \mathrm{mg} / \mathrm{kg}$ this increase persisted for 180 and 240 min, respectively. The data show that EOCz is effective as an antinociceptive agent.

Croton zehntneri is an aromatic plant native to Northeastern Brazil, where it is popularly called "Canela de Cunhã" and used in folk medicine principally as a sedative, as an appetite-stimulating antianorexigen, and for the relief of gastrointestinal disturbances (1). Despite this, little pharmacological investigation has been carried out on the effects of $C$. zehntneri.

Published research on plant extracts has focused primarily on the central nervous system $(2,3)$ and on muscle (4-7). We have previously shown that the essential oil of $C$. zehntneri $(\mathrm{EOCz})$ exerts antispasmodic effects on guinea pig-isolated ileum $(4,6)$, pos-

\section{Key words}

- Croton zehntneri

- Essential oil

- Analgesic

- Antinociception

- Formalin test

- Hot-plate test sibly explaining the use of $C$. zehntneri in the treatment of gastrointestinal problems. However, it is not currently known whether such effects of $\mathrm{EOCz}$ originate exclusively from antispasmodic activity or also due to the contribution of other effects.

Because many essential oils possess potent analgesic activity, in the present study we investigated whether $\mathrm{EOCz}$ possesses antinociceptive activity. The data suggest that EOCz also has an analgesic action.

C. zehntneri leaves were collected in September, 1998, near the city of Viçosa, MG, Brazil. The botanical identity of the plant was confirmed by Dr. Francisco J. Abreu 
Matos (Natural Products Laboratory, Universidade Federal de Ceará, UFC) and Dr. Raymond Harley (Royal Botanic Garden, Kew, UK). A voucher specimen (\#27477) is deposited in the Prisco Bezerra herbarium (UFC).

EOCz was extracted from freshly chopped plant leaves by steam distillation and analyzed at the Natural Products Laboratory of UFC. Freshly chopped leaves were placed in a glass flask connected at one end to a glass vessel with water and at the other end to a water-cooled condenser. When the water was boiled, steam percolated through the leaves and was collected in the condenser. After condensation, the essential oil separated from the aqueous phase with its solutes. The composition (w/w) of EOCz, determined by gas chromatography and mass spectrometry, was $85.7 \%$ anethole, $4.8 \%$ estragole, $2.95 \%$ 1,8cineole, $2.2 \%$ B-myrcene, $1.22 \%$ anisaldehyde, $0.9 \%$ trans-caryophyllene, and $2.23 \%$ unidentified.

EOCz solutions were prepared each day by vigorous manual shaking (3-5 $\mathrm{min}$ ) or by vortexing EOCz in vehicle (1\% Tween 80 in distilled water). $\mathrm{EOCz}$ was administered orally in a volume of $0.1 \mathrm{ml}$ solution $/ 10 \mathrm{~g}$.

Tween 80 was obtained from Sigma (St. Louis, MO, USA). Acetic acid and formalin were from Reagen (Rio de Janeiro, RJ, Brazil).

All experiments were conducted on male Swiss mice (25-30 g) deprived of food, but with free access to drinking water during the $12 \mathrm{~h}$ prior to experiments. EOCz solubilized in vehicle (1\% Tween 80 , aqueous solution) or vehicle only (control) was administered orally with an orogastric cannula, $60 \mathrm{~min}$ prior to nociceptive testing. Animals were kindly provided by the vivarium of UFC. The number of animals in each control and experimental group varied from 6 to 12 .

The formalin test was done as described by Hunskaar et al. (8). Briefly, $20 \mu \mathrm{l}$ of a $0.1 \%$ (v/v) aqueous formalin solution was injected into the plantar region of the right hind paw. The time that the animal spent licking the paw during the first 5 min (early phase) and from 20 to $25 \mathrm{~min}$ (late phase) post-injection served as a measure of sensitivity. The test was done at an ambient temperature of $22-26^{\circ} \mathrm{C}$ and care was taken to exclude environmental disturbances that might interfere with animal response (9).

The writhing test was performed according to Koster et al. (10). Briefly, $0.1 \mathrm{ml} / 10 \mathrm{~g}$ body weight of an aqueous acetic acid solution $(0.6 \%, v / v)$ was administered by intraperitoneal injection and the number of abdominal contortions was counted from 10 to 30 min post-injection.

The hot-plate test was done according to Carlini (11). Briefly, a mouse was placed on a plate maintained at $50.0 \pm 0.5^{\circ} \mathrm{C}$ and the latency of the reaction to this nociceptive stimulus (number of seconds before it started licking the hind paw or jumping) was quantified. Only mice that had responded in a pretest with a reaction time $\leq 20 \mathrm{~s}$ were employed in these experiments. Mice were tested every $30 \mathrm{~min}$ for up to $3 \mathrm{~h}$ starting $1 \mathrm{~h}$ after EOCz treatment.

Results are reported as mean $\pm \mathrm{SEM}$, with $\mathrm{N}$ indicating the number of animals. Values were analyzed using the Student $t$ test, ANOVA, or a nonparametric test as appropriate, and were considered to differ significantly at $\mathrm{P} \leq 0.05$.

In the formalin test, the number of seconds that control mice spent licking their paws in the first and second phases of the response to formalin injection was $58.2 \pm$ $7.02(\mathrm{~N}=6)$ and $41.6 \pm 8.62(\mathrm{~N}=6)$, respectively. EOCz significantly reduced this time ( $\mathrm{P} \leq 0.05$, ANOVA, Dunn's test) in the second phase, at doses of 100 and $300 \mathrm{mg} / \mathrm{kg}$ to $12.01 \pm 7.97(\mathrm{~N}=6)$ and $6.57 \pm 3.42(\mathrm{~N}=$ 10 ), respectively. During the first phase of the formalin test only $300 \mathrm{mg} / \mathrm{kg}$ induced a significant alteration (from 58.2 \pm 7.02 , control, to $28.7 \pm 4.73 \mathrm{~s}, \mathrm{~N}=10$ ) (Figure 1).

In the acetic acid-induced writhing test, the number of contortions occurring in control mice was $80.6 \pm 7.01(\mathrm{~N}=6)$. In animals 
that received $300 \mathrm{mg} / \mathrm{kg} \mathrm{EOCz}$ the number of contortions $(89.1 \pm 9.53 \%$ of control, $\mathrm{N}=$ 6) was not significantly altered relative to controls ( $\mathrm{P} \geq 0.05$, Student $t$-test).

In the hot-plate test, $30 \mathrm{mg} / \mathrm{kg}$ EOCz did not alter the hot-plate response; however, doses $\geq 100 \mathrm{mg} / \mathrm{kg}$ significantly increased response latency compared with controls $(11.2 \pm 0.8 \mathrm{~s}, \mathrm{~N}=10)$. At 100 and $300 \mathrm{mg} / \mathrm{kg}$ this response persisted at statistically significant levels for $180 \min (24.7 \pm 2.57 \mathrm{~s}, \mathrm{~N}=9)$ and $240 \mathrm{~min}(25.0 \pm 0.57 \mathrm{~s}, \mathrm{~N}=7)$, respectively (Figure 2).

EOCz showed an antinociceptive effect in the hot-plate test and in both phases of the formalin test, although its effect during the first phase of the formalin test was significant only with $300 \mathrm{mg} / \mathrm{kg}$. EOCz also showed no effect in the acetic acid-induced writhing test. The hot-plate test results suggest that this analgesic agent acts primarily at the spinal cord and/or higher central nervous system levels, or by an indirect mechanism (12). The two phases of response to the formalin test have been attributed to different mechanisms $(9,13,14)$. The first phase of the formalin test, not pronouncedly altered by $\mathrm{EOCz}$, is attributed to peripheral mechanisms. The second phase, which is conspicuously affected by $\mathrm{EOCz}$, is considered to be due to alteration of central processing. This agrees with the hypothesis of a central mechanism as the major causative factor for $\mathrm{EOCz}$ induction of antinociceptive effects. On the other hand, contortions induced by intraperitoneal injections of acetic acid are said to originate from the pain of inflammation mediated by prostaglandins (15-17). Experiments not included in the results of this study showed that $300 \mathrm{mg} / \mathrm{kg} \mathrm{EOCz}$ did not alter mouse motor performance in the rotorod test. This effect and the lack of EOCz-induced effect in the writhing test suggest that doses lower than $300 \mathrm{mg} / \mathrm{kg}$ EOCz have no general depressant effect.

In the present study we did not attempt to elucidate the contribution of the known con- stituents of $\mathrm{EOCz}$ to the antinociceptive effects of this oil. However, the likelihood of the contribution of two constituents, i.e., anethole $(85.7 \%, \mathrm{w} / \mathrm{w})$ and $\beta$-myrcene $(2.2 \%$, $\mathrm{w} / \mathrm{w})$ to the observed effect should be mentioned. Anethole, present in $\mathrm{EOCz}$ at a high concentration, is documented to have antiinflammatory activity and is chemically similar to eugenol, which has antinociceptive and anti-inflammatory activity (18). BMyrcene, although representing only a small percentage (2.2\%) of the weight of the EOCz, has been documented to be a potent antinociceptive agent, effective at 10 and $20 \mathrm{mg} /$ $\mathrm{kg}$, ip $(19,20)$, and therefore might have contributed to the antinociception induced by a higher dose of EOCz. With respect to
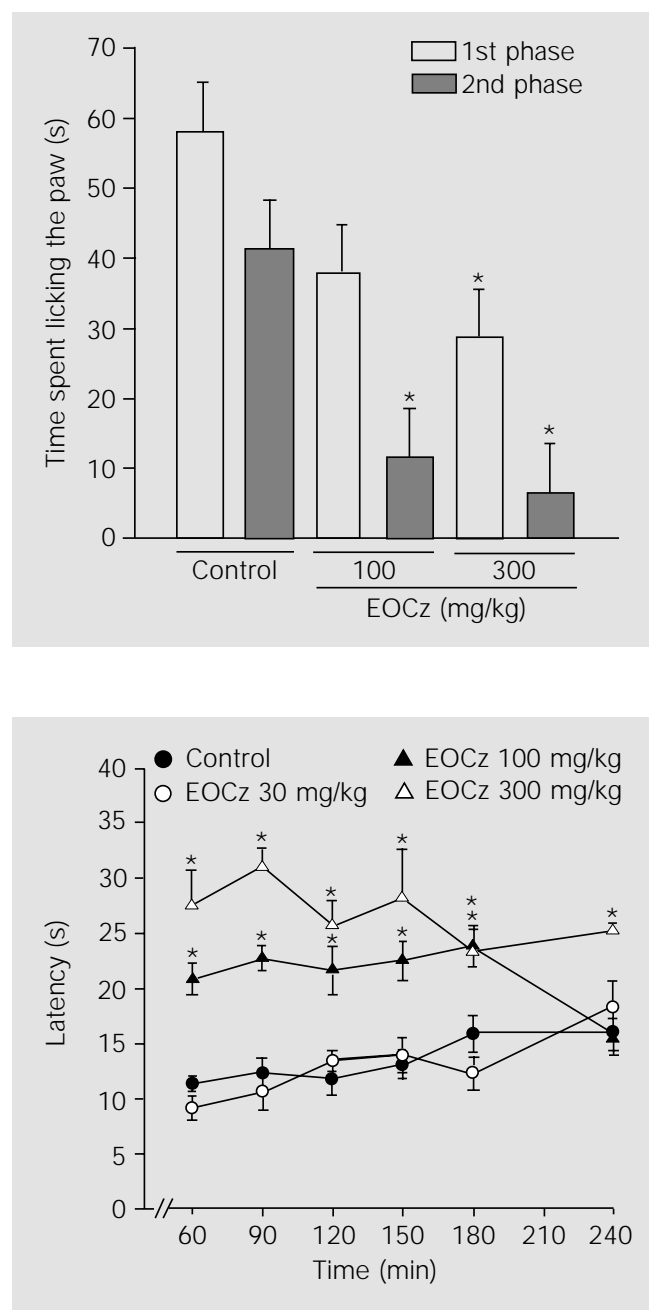

Figure 1. Effects of the essential oil of Croton zehntneri (EOCz) on nociceptive responses to intraplantar injection of formalin (1\%). Ordinate values refer to the time (in s) mice spent licking the paw. Data are reported as means \pm SEM $(\mathrm{N}=6)$. $* \mathrm{P}<0.05$ compared to control (ANOVA, Dunn's test).

Figure 2. Effects of the essential oil of Croton zehntneri (EOCz) on thermal nociception in mice submitted to the hot-plate test. Abscissa, time (min) after oral administration of EOCz. Ordinate, latency (s) for the response to thermal stimulation $(50 \pm$ $0.5^{\circ} \mathrm{C}$ ). Data are reported as means \pm SEM $(\mathrm{N}=10)$ for each EOCz dose. *P<0.05 compared to control at a given time (ANOVA, Dunn's test). 
this hypothesis, it should be noted that at 300 $\mathrm{mg} / \mathrm{kg}$ EOCz was effective during both phases of the formalin test, as expected for an agent acting on opioid receptors. It has also been demonstrated (19) that $\beta$-myrcene-induced antinociception is partially blocked by naloxone. Further investigation is necessary to elucidate this effect.

In conclusion, $\mathrm{EOCz}$ is likely to be acting through a central nervous system mechanism or via an indirect, perhaps anti-inflammatory effect and the elucidation of its mechanism of action deserves further investigation. Unpublished experiments performed in this laboratory indicate that $\mathrm{EOCz}$ has an oral $\mathrm{LD}_{50}>2.5 \mathrm{~g} / \mathrm{kg}$. Since EOCz displays an antinociceptive effect at doses well below the $\mathrm{LD}_{50}$, this effect is potentially useful in therapeutics, and this essential oil deserves further pharmacological investigation.

\section{Acknowledgments}

We would like to thank Dr. Afranio A. Craveiro and Iracema Lacerda Machado for encouragement and for kindly performing the chemical analysis of EOCz, and Drs. Vietla Satyaranayana Rao, Francisco J.A. Matos, Steven D. Aird and Talapala G. Naidu for discussion and encouragement.

\section{References}

1. Craveiro AA, Fernandes AG, Andrade CHS, Matos FJ A \& Alencar JW (1977). Óleos essenciais de canelas silvestres regionais. Ciência e Cultura, 29: 445 (Abstract).

2. Bernardi MM, Desouza-Spinoza $H$, Batatinha MJ M \& Giorgi R (1991). Croton zehntneri possible central nervous system effects in rodents. J ournal of Ethnopharmacology, 33: 285-287.

3. Giorgi R, Batatinha MJ M, Bernardi MM, DeSouza-Spinosa $H$, Spinosa FRN \& Palermo-Neto J (1991). Effects of Croton zehntneri aqueous extracts on some cholinergic- and dopaminergic-related behaviours of laboratory rodents. J oumal of Ethnopharmacology, 34: 189-193.

4. Albuquerque $A A C$, Sorenson $A L \&$ LealCardoso J H (1995). Effects of oil of Croton zehntneri, and of anethole and estragole on skeletal muscles. J oumal of Ethnopharmacology, 49: 41-49.

5. Coelho-de-Souza AN, Barata EL, MagaIhães PJ C, Lima CC \& Leal-Cardoso J H (1997). Effects of the essential oil of Croton zehntneri, and its constituent estragole on intestinal smooth muscle. Phytotherapy Research, 11: 299-304.

6. Coelho-de-Souza AN, Criddle DN \& LealCardoso J H (1998). Selective and modulatory effects of the essential oil of Croton zehntneri on isolated smooth muscle preparations of the guinea pig. Phyto- therapy Research, 12: 189-194.

7. Leal-Cardoso J H \& Fonteles MC (1999). Pharmacological effects of essential oils of plants of the Northeast of Brazil. Anais da Academia Brasileira de Ciências, 71: 207-213.

8. Hunskaar S, Fasmer OB \& Hole K (1985). Formalin test in mice, a useful technique for evaluating mild analgesics. J oumal of Neuroscience Methods, 14: 69-76.

9. Tjölsen A, Berge OG, Hunskaar S, Rosland J H \& Hole K (1992). The formalin test: an evaluation of the method. Pain, 51: 5-17.

10. Koster R, Anderson $M \&$ \&ebeer EJ (1959). Acetic acid for analgesic screening. Federation Proceedings, 18: 412 (Abstract).

11. Carlini ELA (1973). Farmacologia Prática Sem Aparelhagem. Savier, São Paulo, 192.

12. Yaksh TL \& Rudy TA (1977). Studies on the direct spinal action of narcotics in the production of analgesia in the rat. J ournal of Pharmacology and Experimental Therapeutics, 202: 411-428.

13. Hunskaar S \& Berge K (1986). Dissociation between antinociceptive and antiinflammatory effects of acetylsalicylic acid and indomethacin in the formalin test. Pain, 25: 125-132.

14. Rosland J H, Tjölsen A, Maehle B \& Hole K (1990). The formalin test in mice: effect of formalin concentration. Pain, 42: 235-242.
15. Northover BJ (1963). The permeability to plasma protein of the peritoneal blood vessel of the mouse and the effect of substances that alter permeability. J ournal of Pathology and Bacteriology, 85: 361-370.

16. Gyres K \& Knull J (1975). Inflammation and writhing syndrome inducing effect of $\mathrm{PGE}_{1}, \mathrm{PGE}_{2}$ and the inhibition of these actions. Polish J oumal of Pharmacology and Pharmacy, 27: 257-264.

17. Collier HOJ, Dinneen LC, J ohnson CA \& Schneider C (1968). The abdominal constriction response and its suppression by analgesic drugs in the mouse. British J oumal of Pharmacology, 32: 295-310.

18. Chainy GBN, Manna SK, Chaturvedi MM \& Aggarwal BB (2000). Anethole blocks both early and late cellular responses by tumor necrosis factor: effect on NF-kB, AP-1, J NK, MAPKK and apoptosis. Oncogene, 19: 2943-2950.

19. Rao VS, Menezes AM \& Viana GS (1990). Effects of myrcene on nociception in mice. J ournal of Pharmacy and Pharmacology, 42: 877-878.

20. Lorenzetti BB, Souza GE, Sarti SJ , SantosFilho D \& Ferreira SH (1991). Myrcene mimics the peripheral analgesic activity of lemongrass tea. J oumal of Ethnopharmacology, 34: 43-48. 